arranged suitably under the different heads. These questions and notes were then sent round to all the organizations for thorough study, ensuring that the discussions at the venue would be well informed and fruitful. The entire material has now been brought together in a booklet, Castorseed and its Products (Pp. viii +87 . Hyderabad: Indian Central Oilseeds Committee. 1961). It includes the questions raised, the notes received and the discussions which later took place at the sessions. Though the seminar dealt primarily with castor in its Indian setting, the material in this booklet might well have a wider interest.

\section{National Council for Technological Awards}

THE report of the National Council for 'Technological Awards for the period April 1960 to March 1961 (London : National Council for Technical Awards. Pp. 37) records that nearly 5,000 students were following courses leading to the diploma in technology, compared with 3,800 a year ago, and 309 diplomas were awarded, bringing the total to 472 . Approximately 83 per cent of the engineering students and 56 per cent of students of other technologies are working in industry, and the Council is impressed by the increase in the number of students following sandwich courses in technologies other than engineering, from 219 in November 1957 to 1,246 at the end of the year under review; for engineering sandwich courses the corresponding figures are 652 and 3,191 . Of 1,769 students enrolled in first-year courses leading to the diploma in the current session, 63 were women. Almost 25 per cent of these students entered their courses by virtue of holding good Ordinary National Certificates, and the Council points out that but for the development of these courses few of these students would have had an opportunity of gaining a qualification equivalent in standard to a university honours degree, and many might never have been added to the nation's technological man-power. The diploma is now accepted as a qualification for entry to the Scientific Civil Service equivalent to a university degree, and most professional institutions exempt holders of the diploma from taking the whole of their own examinations for graduate membership. The Council expresses appreciation of two awards from the Nuffield Foundation in support of study of the nature of courses leading to the diploma : one at the Brunel College of Technology concentrates on the relation of college periods of study to industrial training periods, and the other at the Birmingham College of Advanced Technology is concerned with the spacing of industrial and college training with the object of assembling a body of thought and opinion as a basis for deciding whether changes are needed to improve the quality of industrial and college training, increase the numbers attending advanced courses, and mobilize more effectively the teaching and research resources of colleges and companies. List No. 13 issued also by the Council details 100 existing and 13 proposed courses leading to the diploma.

\section{The Calouste Gulbenkian Foundation, Lisbon}

THE trustees of the Calouste Gulbenkian Foundation, Lisbon, have announced the grants made during the first half of 1961 , which total about $£ 360,000$, and, of which, grants in the United Kingdom and British Commonwealth total nearly $£ 100,000$. Again they include grants for three years to British under- graduate scientific expeditions, as follows: $£ 200$ to the Royal Geographical Society in aid of the expeditions; $£ 200$ to the University of Leicester expedition to East Greenland; $£ 200$ to the University of Wales expedition to Mount Sabalan; $£ 150$ to the Cambridge Arctic Canada expedition; $£ 100$ to the University of Oxford expedition to the Andes of Peru; $£ 100$ to the University of Oxford expedition to the Atlas Mountains of Southern Morocco; $£ 100$ to the Cambridge expedition to Nagir, Karakoram; £100 to the Oxford expedition to the South Caspian; and £50 to the University of Oxford women's expedition to the Madeiras. The grants made in aid of education in Great Britain and the Commonwealth total $£ 41,800$, including: $£ 15,000$ to the School of Oriental and African Studies, University of London; $£ 4,500$ to the Science Masters' Association; $£ 3,900$ for three years to the School Library Association. In Portugal, $\$ 56,241$ has been granted in aid of science and medicine, including grants for the Santa Maria Hospital, Lisbon, for biochemistry at the University of Oporto, the Laboratory of Mass Spectrometry of the Nuclear Energy Study Commission and the Centre of Geological Studies, Lisbon. A total of $£ 7,500$ has been given to the Faculty of Engineering of the University of Baghdad. Other countries receiving grants include Brazil $(£ 8,508)$ and France $(£ 2,612)$. Grants have also been made to the World Federation for Mental Health and the International Union against Cancer.

\section{Fellowships for Plankton Research}

IN order to encourage research relating to plankton in the western North Atlantic, the Lamont Geological Observatory is offering several fellowships for independent studies in this field. These fellowships are open to qualified scientists of any nationality, and include transportation costs from home to Sandy Hook, New Jersey, and return, plus a stipend which will be limited ordinarily to 1,500 dollars. Applications and requests for further information should be addressed to the Director, Sandy Hook Marine Laboratory, P.O. Box 428, Highlands, New Jersey.

\section{Carlsberg-Wellcome Travelling Research Fellow- ships}

ThE Carlsberg Foundation (Copenhagen) and the Wellcome Trust (London) have announced the award of Carlsberg-Wellcome Fellowships for 1960-61 to: Dr. E. Poulsen, senior Lecturer at the Royal Veterinary and Agricultural College, Copenhagen, who will work at the Medical Research Council's Toxicology Research Unit at Carshalton on the neurotoxic influence of alicyclic phosphates and similar compounds; Dr. A. F. Hayward, of the Anatomy Department of the University of Glasgow, who will work at the Carlsberg Laboratory in Copenhagen, under the direction of Dr. H. Holter, studying the electron microseopic appearances in pinocytosis; Dr. S. L. Rowles, a member of the external scientific staff of the Medical Research Council at the School of Dental Surgery in Birmingham, who will work with Dr. Tovborg Jensen of the Royal Veterinary and Agricultural College, Copenhagen, on the chemistry of the calcium phosphates with special reference to those occurring in oral tissues.

\section{Society for Applied Bacteriology}

Ax the annual meeting of the Society for Applied Bacteriology held in Wye on July 11 the following 